\title{
Jurisdictional Overlap \& the Size of the Local Public Workforce $^{*}$
}

\author{
Christopher B. Goodman University of Nebraska at Omaha
}

The United States is a country of many overlapping local governments. Theoretical explorations of the potential influence of this institutional arrangement abound; however, empirical evidence as the influence of such an arrangement on local public sector remains relatively thin. Instead of competing for mobile resources as suggested by Tiebout, overlapping jurisdictions utilize similar tax and voting bases introducing a potential commons problem. Using a county-level dataset from 1972 to 2012, this commons problem is explored. The results suggest that a positive relationship between jurisdictional overlap and the size of local public workforce amounting to approximately a one percent increase in employment or an increase of less than one full-time equivalent employee.

Keywords: public employment, Tiebout, inter-jurisdictional competition

\section{Introduction}

Special districts are the most abundant and fastest growing kind of local government in the United States. In 2012, special districts numbered more than 38,000. In addition to their large numbers, the growth in special districts has been equally large, growing 210 percent since 1952 with an average annual rate of growth of 1.9 percent. $^{1}$ As Stephens and Wikstrom (1998) note, special districts are increasingly "professionalized;" adding full time staff and providing services similar to general purpose local governments. Special districts are somewhat unique in the U.S. system of local governments. Rather than having jurisdictional boundaries that abut, special districts are largely overlapping, resulting in a vertical layering of local government. Instead of competing for residents as general purpose local governments do, these vertically layered governments are providing a variety of public services to a single population. This institutional arrangement has the potential to create a commons problem, leading to a bias toward a larger local government sector. By failing to take other special district's decisions into account, individual special districts can become inefficiently large.

Previous literature has examined the role of increased vertical layering of local government (jurisdictional overlap) on local revenues. Estimates of this "overlap effect" range between 5 to 25 percent of local revenues (Berry 2008). However, it is equally likely that size of the local public workforce may be increased to an inefficiently large amount. Local government is a laborintensive operation and one could assume that inflated revenues could be used to fund additional local public-sector employees. This analysis extends the work of Berry $(2008,2009)$ to examine this potential effect. Specifically, this paper addresses the question of what the effect of jurisdictional overlap of special districts is on local full-time equivalent public employment per capita.

${ }^{*}$ Abbreviated version published at State \& Local Government Review 50 (1): 15-23. 
The findings of Berry $(2008,2009)$ suggests a common pool resource problem leading to a positive relationship; however, the size of the effect is unknown. An important difference in theoretical motivation between this paper and the work of Berry is the power to tax by special districts is not required, thus making this analysis a generalization of Berry's work.

The analysis proceeds as follows. The next section explores the institutional context of special districts in the United States and explains the potential for a common-pool resource problem. Next, data, model and methodology of the analysis are explored. The next section presents the primary results and model extensions are explored. Finally, conclusions and policy implications are discussed.

\section{Background}

\section{Special Districts in the U.S.}

Special districts are autonomous governments that, by virtue of their creation, provide a single or very limited set of public services (Foster 1997; Goodman and Leland 2012). The typical special district can raise revenues, issue debt, set its territorial boundaries within the limits of its creating legislation, and deliver public services. The importance of this kind of local government is often understated. Special districts are the most abundant form of local governments in the United States. As of 2012, special districts represented 42.5 percent of all local governments. ${ }^{2}$ In addition to their significant current presence, the net growth of special districts has been large, growing 210 percent since 1952 with an average annual rate of growth of 1.9 percent. This is compared to negative growth for counties, towns/townships, and independent school districts and only modest growth for municipalities (16.14 percent since 1952). Even with their importance to the local public sector, relatively little scholarly research is conducted on them.

Foster $(1997)$ and Berry $(2008,2009)$ explain there are two primary schools of thought on the role of special purpose governments in the U.S. The institutionalists perspective posits that special districts contribute to the further fragmentation of metropolitan governance and lead to duplications in service delivery and increased administrative inefficiencies (Bollens 1957; Advisory Commission on Intergovernmental Relations 1964). A further problem of low political visibility of special districts led to little support for this institutional arrangement (Foster 1997). ${ }^{3}$ The Public Choice perspective (or administrative reformers as Stein (1989) refers to them) suggests that special districts can be a useful tool in bridging the gap between public service production and public service provision (Ostrom, Tiebout, and Warren 1961). For instance, a small community may wish to provide mass transit services to its residents; however, the jurisdiction is too small to provide the services in a cost-effective manner. A mass transit district composed of multiple adjoining cities pooling their resources can provide the service in a more efficient manner. Ultimately, special districts are seen as a complement to general purpose local governments, increasing flexibility in public service provision (Advisory Commission on Intergovernmental Relations 1987).

The U.S. Census Bureau (2013, ix) defines a special district as "independent, special purpose governmental units, other than school district governments, that exist as separate entities with substantial administrative and fiscal independence from general purpose local governments." The autonomy of special districts is a key aspect of this analysis. The Census Bureau defines "substantial autonomy" on two dimensions. Fiscal independence includes the power to independently adopt a budget without review from another organization, to determine the level of taxation or other revenues, or issue debt without review from another government (U.S. Census Bureau 2013). The 
second is administrative independence. Fiscal independence is a necessary condition for administrative independence and further requires either (1) a popularly elected governing body, (2) a governing body representing two or more state or local governments, or (3) an appointed governing body substantially different from the creating government. Violation of either of these dimensions leads the Census Bureau of classify these special purpose governments as "dependent" and are excluded from the data. ${ }^{4}$

In addition to their definition by the Census Bureau, special districts are defined by the way in which they are spatially arranged. Rather than being arranged with boundaries abutting each other as municipalities are, special districts have territorial flexibility that leads to overlapping jurisdictions (Bollens 1957). The boundaries of special districts are generally not required to be coterminous with each other or with any other general purpose local government. This territorial flexibility leads to a significant departure from the traditional Tiebout (1956) competition model. Under the Tiebout model, non-overlapping local governments compete for mobile fiscal resources by offering different bundles of public services at different tax prices. Individuals choose their residential location based off which bundles most closely satisfy their preferences. When jurisdictions overlap, the connection between the bundle of public services and the tax price imposed by each individual government is uncoupled. An example is illustrative. Consider the example from Tiebout where an individual is choosing where to live. If all public services are provided by a series of overlapping special districts, the provision of these public services is unbundled. However, the choice or consumption of public service provision is not. The number and quality of public services is still based on location (similar to Tiebout). A similar story can be told about taxation. Aggregate tax price faced by the individual works similar to the Tiebout model; however, the process by which each individual tax price is set is done through a number of overlapping governments who have little incentive to pay attention to what each other are doing. Rather than competing for mobile fiscal resources, special districts are providing public services to and collecting revenues from the same set of residents. This provides the circumstances for a common pool problem.

\section{The Common Pool Problem}

Berry (2009) formalizes the common pool problem associated with jurisdictional overlap. The primary concern is a number of vertically overlapping jurisdictions are providing services that are consumed as a bundle by residents. If each overlapping special district is run by a benevolent central planner, the planner maximizes the welfare of the residents of the jurisdiction while internalizing any costs imposed on other jurisdictions in the process. The optimal provision of public goods occurs where marginal social cost equals marginal social benefit. When this occurs, the provision of public good is identical if it is provided by a collection of overlapping jurisdictions or by a single general-purpose government. ${ }^{5}$ If this is the case, there will be no relationship between jurisdictional overlap and the level of public employment in a particular area.

There are a number of issues that stand in the way of the optimal situation occurring. The assumption of an omniscient, benevolent central planner is hardly realistic. Even an appropriately public service minded individual or governing board is unlikely to be able to perceive all of the pitfalls necessary to achieve the socially optimal outcome. The governing bodies of special districts are particularly susceptible to "capture" by regulated interests (Stigler 1971) or, at the very least, face a large collective action problem (Olson 1965). Since special districts often provide specialized benefits funded from reasonably broad-based revenues, the beneficiaries of such public 
services will exert lobbying pressure on the district to provide more or better services to benefit them (Bauroth 2005). This lobbying is further hidden by the election and appointment processes of special districts. ${ }^{6}$ Usually held in off years, local elections have notoriously low turnout and special district elections are even lower (Hudson 1996; Little Hoover Commission 2000). Additionally, special district governments are exempt from "one person/one vote" norms of federal, state, and local elections (Briffault 1993). Indeed, Bauroth (2007) finds that limiting voting to only landowners appreciably changes the fiscal decision-making of special districts.

The above circumstance does not require anyone (elected officials or voters) to do anything other than act in their own interests. For elected officials, whose main objective is to be re-elected, favoring policies that benefit groups of voters who actually vote in their elections is a means to an end, particularly when the salience of the issue is high (Mullin 2008). When issue salience is low, the policies favored by special districts are likely to differ substantially from the collection of policies favored by general purpose local governments whose elected representatives often substitute their own preferences in the absence of information on voter preferences (Mullin 2008). ${ }^{7}$ Another potential issue is that elected or appointed members of special district boards may have self-selected into these positions because they value the public good or service provided by the district (Berry 2008). One would expect those representatives to advocate for more of whatever public good or service is being provided. These particular preferences would be forced to compete with other interests in a general purpose government; however, due to the single function nature of many special districts, the preference for higher levels of spending or service provision can prevail. One might expect the board of a transit district to prefer to deliver significantly more transit services than the council of a city who has to balance transit services with all the other services provided by the city.

\section{Data \& Methods}

\section{Data}

Following nearly all research of special purpose local governments, the data for this analysis is from the U.S. Census of Governments. Much has been written about the deficiencies of these data, particularly in regard to special districts (Leigland 1990); however, it is the only nationally representative data source available over time (Foster 1997). It is important to note that even the most basic information on the service delivery areas of special districts such as population or land area served are not available. This severely limits the ability to calculated an exact measure of jurisdictional overlap the individual parcel or municipality level. Following Berry $(2008,2009)$, jurisdictional overlap is defined as the number of special purpose local governments per municipality in a county area. As each resident only faces one municipality, this operationalization measure the effective number of vertically stacked local governments faced by the average resident in a county area. ${ }^{8}$ For example, if one examines two similar independent cities, Baltimore City, MD and St. Louis City, $\mathrm{MO},{ }^{9}$ ones finds vastly different jurisdictional overlap. Baltimore City has three special districts per one municipality; however, St. Louis has 36 special districts per one municipality. St. Louis has twelve times the number of special districts for a population of roughly half that of Baltimore. Unlike Berry $(2008,2009)$, special purpose governments without taxing authority have not been excluded from the data. While Berry was concerned with the issue of concurrent taxation in a vertical fragmented environment, this analysis is concerned with the potential ramifications of elected officials doling out specific benefits (public sector jobs) when costs are diffuse. Taxation 
isn't a requirement for this relationship to exist; only revenues (from any source) sufficient to pay wages.

While models of the determinants of public sector wages are plentiful in the literature, a comprehensive model of the demand for state-local or local public employees is elusive. The work of Ehrenberg $(1973,1972)$ is a notable exception. Ehrenberg (1972) suggests the following relationship.

$$
N=f\left(w_{p}, Y, G, w_{r}, X\right)
$$

Where public employment per capita $(N)$ is a function of public sector wages $\left(w_{p}\right)$, income per capita $(Y)$, grants-in-aid $(G)$, relative wages of the private sector $\left(w_{r}\right)$ and other sociodemographic factors $(X)$.

Equation 1 assumes that the central planner can choose the entire employment portfolio in each period. The assumption is likely too flexible. In reality, there are a number of restrictions put on public decision-makers with regard to the employment portfolio such as union contracts and tenure rights that limits the change in public employment from year to year. Therefore, the public employment portfolio is likely a function of previous years' portfolios. A one-period and two-period lag of the dependent variable is included to account for the restrictions on decision making. Following Ehrenberg (1972), the equation for the demand for local public employees is the following.

$$
\begin{aligned}
L N_{i t}= & \alpha+\beta L N_{i t-T}+\sum_{1}^{j} \kappa_{j} L w_{i t}+\sum_{1}^{k} \rho_{k} L Y_{i t}+\sum_{1}^{l} \delta_{l} L X_{i t} \\
& +\eta L O V E R L A P_{i t}+\phi_{i}+\gamma_{t}+\varepsilon_{i t}
\end{aligned}
$$

Where, $L N$ equals full-time equivalent employees per 1,000 residents in county area $i$ in time $t$, $L w$ is a vector of variables measures wages in the public and private sectors for county area $i$ in time $t, L Y$ measures the wealth of residents for county area $i$ in time $t, L X$ is a vector of variables measuring sociodemographic factors influencing employment demand for county area $i$ in time $t, L O V E R L A P$ is the ratio of special purpose governments to municipalities in county area $i$ in time $t$ in natural logarithms, ${ }^{10}$ and $\varepsilon$ is the usual composite error term. Additionally, time $(\gamma)$ and county are $(\phi)$ fixed effects are included.

As suggested by Ehrenberg (1972), there are a number of variables included in the model that seek to explain the demand for local government employees. Principle among these variables is labor price as operationalized as the natural logarithm of average monthly payroll per full-time public employee. It is assumed that public employees are normal goods; therefore, the influence of price is expected to be negative. Additionally, the natural logarithm of the ratio of average monthly payroll per full-time public worker to the average monthly earnings of private, non-farm workers is included. This controls for differences in the relative cost of public provided goods to privately provided goods. Similar to public sector wages, it is expected there be an employment disincentive when public sector wages rise relative to private sector wages leading to a negative sign prediction for this variable. Personal income and grants from higher levels of government per capita are included to control for the total resources of a community. It is expected that the influence of these two variables be positive on public sector employment. Finally, sociodemographic are included to control for the tastes of the community. Specifically, population density, the proportion of population under the age of 19 and the the proportion of the population over the age of 65 are included in the models. 
Table 1: Summary Statistics

\begin{tabular}{|c|c|c|c|c|c|c|c|}
\hline Variable & Source & Units & Mean & p25 & p50 & p75 & St. Dev. \\
\hline FTE employees & COG & FTE per 1,000 & 41.28 & 32.37 & 38.20 & 46.34 & 14.99 \\
\hline Jurisdictional overlap & COG & Ratio & 3.43 & 1 & 2.29 & 4.20 & 4.40 \\
\hline Special district overlap & COG & Ratio & 2.10 & 0.57 & 1.18 & 2.33 & 3.46 \\
\hline Special district + town overlap & COG & Ratio & 2.64 & 0.70 & 1.63 & 3.33 & 3.74 \\
\hline Public wages & COG & \$ per month & 2705.45 & 2293.87 & 2606.60 & 3006.07 & 606.20 \\
\hline Public wages relative to private wages & COG & Ratio & 1.18 & 1.00 & 1.15 & 1.33 & 0.30 \\
\hline Federal aid, per capita & COG & $\$$ per capita & 103.64 & 31.09 & 64.05 & 122.26 & 173.71 \\
\hline State aid, per capita & COG & $\$$ per capita & 1076.30 & 718.88 & 975.31 & 1300.81 & 589.45 \\
\hline Personal income, per capita & REIS & $\$$ per capita & $24,757.52$ & $19,282.63$ & $23,516.21$ & $28,655.16$ & 8073.71 \\
\hline Population density & REIS & Per square mile & 175.53 & 17.59 & 41.69 & 100.45 & 836.10 \\
\hline Population over 65 & SEER & Fraction & 0.15 & 0.12 & 0.15 & 0.18 & 0.04 \\
\hline Population under 19 & SEER & Fraction & 0.29 & 0.26 & 0.29 & 0.31 & 0.04 \\
\hline
\end{tabular}

The primary data for this analysis are derived from nine consecutive Census of Governments (COG) from 1972 to 2012. The census is conducted on an every five year basis. This results in data from 1972, 1977, 1982, 1987, 1992, 1997, 2002, 2007, and 2012. The remaining data in the dataset is derived from Regional Economic Information System (REIS) of the Bureau of Economic Analysis and the Surveillance, Epidemiology, and End Results (SEER) program at the National Cancer Institute. To allow for comparability over time, the local governments in Alaska and the smaller independent cities in Virginia have been dropped from the dataset. ${ }^{11}$ This results in an unbalanced panel of 20,765 observations over 3,021 county areas. See table 1 for summary statistics for all variables employed in this analysis.

\section{Methods}

The proposed model in equation 2 has potentially two econometric issues that may bias the estimation. First, the addition of a one- and two-period lag of the dependent variable on the righthand side of the estimating equation introduces an endogeneity making OLS an inappropriate estimating technique. To overcome the endogeneity, estimation will proceed with the dynamic panel method outlined in Arellano and Bover (1995) and fully specified in Blundell and Bond (1998). ${ }^{12}$ This method is superior to the method in Arellano and Bond (1991) because it is designed for dynamic small $T$, large $N$ estimation and can accommodate heteroskedastic and autocorrelated error structures.

Second, this analysis potentially suffers from a potential simultaneity bias. That is, local policy makers potentially create special purpose governments with the express intent to increase the size of the local public workforce. If this is the case, jurisdictional overlap will be correlated with the composite error term $(\varepsilon)$ and the standard errors of an OLS model will be biased. A byproduct of the dynamic panel estimation presented above is the wholesale instrumenting for all right-hand side variables with lagged values in levels and differences. This significantly reduces the potential simultaneity between the size of the local public sector and jurisdictional.

The inclusion of county area fixed effects in equation 2 attempts to controls for any unobserved, unvarying characteristics unique to an individual county area. Similarly, the year fixed effects attempt to control for any occurrences common to all county areas in a given year such as economic factors. Across all models presented, standard errors are clustered on the county area to 
deal with any heteroskedasticity or autocorrelation as the result of correlation among each county area specific residual.

\section{Results}

Table 2 presents the main results of this analysis where the dependent variable is full time equivalent (FTE) public employees per 1,000 residents in a county area. The model is estimated using the method outlined in Blundell and Bond (1998) and includes a one- and two-period lag of the dependent variable. As expected, the current years? local public employment is heavily dependent upon the previous two years' levels. The coefficients on the one- and two-period lag can be interpreted as the proportion of current years employment explained by the previous year's levels. The variable of interest, special district overlap, is positive and statistically significant suggesting that a proliferation of vertically overlapping local government enlarges the local public workforce.

It is important to quantify the size of results presented here to provide some context. From table 2, the point estimate of special district overlap is 0.012 . This implies moving from the 25th to the 75th percentile in jurisdictional overlap-from 0.5 to 2.3 special districts per municipality or moving from rural Bradford County, FL (0.5) to suburban Polk County, FL (2.235)-leads to a 1.004 percent increase in FTE employment per 1,000 residents on average. ${ }^{13}$ Taken at the median of the dependent variable (38.20 FTE employees), this is approximately a 0.77 FTE employee increase. This is less than one fifth the effect size found by Berry $(2008,2009)$ suggesting that special districts may be using revenue generated from the overlap effect on things other than more employees.

The remaining controls variable perform has expected. A one percent increase in local public FTE employment in the previous period leads to a 0.559 percent increase in local public FTE employment in the current period. A one percent increase in local public FTE employment two periods ago leads to a 0.119 percent increase in local public FTE employment in the current period. This is a non-trivial relationship. When the coefficients are summed, more than half of the increase in local public FTE employment in the current period is determined by the previous two period?s employment, ceteris paribus. The results found are supportive of the arguments of Ehrenberg $(1972,1973)$ that it is reasonable to expect an amount of incrementalism in the budgeting for local public employment. Certain structural characteristics of public employment (union contracts, some tenure rights) make large changes over time in the level of public employment impossible.

The influence of public sector wages on local public FTE employment is negative. This result suggests that public sector employees can be seen as normal goods. As public employees become more expensive, the quantity demanded of them declines. The ratio of public wages to private wages is also negative and statistically significant. These results suggest that as public sector employees become more expensive relative to private sector employees, the quantity demanded of public sector employees decreases. This result supports that found by Ehrenberg (1972). Per capita personal income exerts a positive and statistically significant influence on per capita local public employment. This result suggests that as community wealth increases so does the quantity demanded of public sector employees. This result is similar to that found in the literature (Bahl, Gustely, and Wasylenko 1978; Ehrenberg 1973, 1972; Schneider 1988, 1989b, 1989a). The influence of state and federal intergovernmental aid is positive with state aid providing more of a stimulus to the local public employment budget than federal aid. This result is in line with that of the literature (Stein 1984; Schneider 1988, 1989a). 
Table 2: Jurisdictional Overlap \& Full-Time Equivalent Public Employment per 1,000 Residents

\begin{tabular}{lc}
\hline & Blundell and Bond \\
& $(1)$ \\
\hline Special district overlap & $0.012^{* *}$ \\
FTE employees per $1,000_{(t-5)}$ & $(8.84)$ \\
& $0.559^{* *}$ \\
FTE employees per $1,000_{(t-10)}$ & $(32.24)$ \\
& $0.119^{* *}$ \\
Public wages & $(9.79)$ \\
& $-0.222^{* *}$ \\
Public wages relative to private wages & $(15.00)$ \\
Federal aid, per capita & $-0.020^{*}$ \\
State aid, per capita & $(2.53)$ \\
& $0.007^{* *}$ \\
Personal income, per capita & $(6.14)$ \\
Population density & $0.087^{* *}$ \\
Population over 65 & $(12.48)$ \\
Population under 19 & $0.188^{* *}$ \\
Constant & $(16.33)$ \\
County Areas & $-0.016^{* *}$ \\
\hline Robust t-statistics in parenthe & $(7.95)$ \\
& $0.071^{* *}$ \\
& $(7.70)$ \\
& $0.208^{* *}$ \\
& $(9.58)$ \\
& $0.883^{* *}$ \\
& $(7.61)$ \\
& 20.769 \\
& 3.021 \\
\hline
\end{tabular}

Robust t-statistics in parentheses. County area and year fixed effects excluded. All variables are expressed in natural logarithms. ${ }^{* *} \mathrm{p}<0.01$, * $\mathrm{p}<0.05$ 
Population density is negative and statistically significant. As a county area becomes denser, the quantity of public sector employees demanded declines. This result may be indicative of some economies of density; however, a more specific test is necessary to confirm these results. Both age related variables are found to exert a positive and statistically significant influence on per capita employment. Overall, these results indicate that the model is functioning as one might expect it to given the theoretical guidance above.

\section{Model Extensions}

The previous section demonstrated a common pool relationship between the extent of jurisdictional overlap and the size of the local public workforce. However, a number of alternative possibilities exist to explain the results presented above. First, one might expect that a county with a large number of overlapping jurisdictions may provide a broader range of local services. Second and related to the first, special districts may be used as a means for general purpose local governments to circumvent tax and expenditure limitations imposed on them by state governments. These two possibilities are explored in this section and presented in table 3 . In all instances, the control variables in the model are identical to the specification in table 2. Due to space limitations, full results are not presented, only coefficients of interest.

Table 3: Model Extensions

\begin{tabular}{lcc}
\hline & Functions & Employment \\
& $(1)$ & $(2)$ \\
\hline Special district overlap & $0.008^{* *}$ & $0.011^{* *}$ \\
& $(4.86)$ & $(5.34)$ \\
Potentially binding TEL & - & -0.001 \\
& & $(0.39)$ \\
Interaction & - & 0.002 \\
& & $(0.76)$ \\
\hline
\end{tabular}

Robust t-statistics in parentheses. All control variables and county area and year fixed effects excluded. All non-dichotomous variables are expressed in natural logarithms. ${ }^{* *} \mathrm{p}<0.01,{ }^{*} \mathrm{p}<0.05$

\section{Public Service Provision}

As Berry $(2008,2009)$ suggests, we might expect that county areas with a broader set of public services provided may also have a large number of special districts. Berry (2008) provides the potential mechanism for this relationship. Interest groups have a strong incentive to lobby for new public services to be provided via a special district. The potential for capture is high; allowing the interest group to provide specific benefits to its members while spreading the costs over many votes (both in and out of the district). An additional potential mechanism is through the service delivery responsibilities of municipal governments. As Stein (1989) demonstrates, newer, more suburban cities tend to be more limited in their functional responsibilities and could utilize special 
districts as a means to provide additional services through contract. Lowering the cost of service provision may also be a mechanism (Ferris and Graddy 1991). Regardless of the exact mechanism, one might expect a relationship between the number of overlapping jurisdictions and the number of service types being provided in a given area and this may explain some of the relationship observed in table 2.

Model 1 in table 3 explores this possibility. The natural logarithm of the number of public services provided is regressed on the same set of variables presented above. The data on services provided comes from the Census of Governments. Different from the finance survey, the employment survey tracks 21 individual public services rather than the 37 expenditure categories in the finance survey. Local governments, on average, employ individuals in just over 13 of the 21 possible service areas and this number has increased over time from 11.6 services in 1972 to 13.3 in 2012. A ten percent increase in jurisdictional overlap leads to a 0.07 percent increase in the number of public services provided by a county area on average. ${ }^{14}$ These results are suggestive that the relationship observed in table 2 can partially be attributed to special districts being created to provide new public services, although the strength of the relationship is weak.

\section{Tax \& Expenditure Limits}

The second potentiality is the role of tax and expenditure limitations (TELs) in driving the number of special districts. Tax and expenditure limits are rarely imposed on special district governments. ${ }^{15}$ This loophole presents municipalities with the ability to circumvent TELs imposed on them by creating special districts outside the reach of such laws. The research in this area is mixed. Nelson (1990) finds a positive relationship between TELs imposed on municipalities and the number special districts in a county area suggesting circumvention may be happening. However, many other studies have found no relationship (Goodman, Forthcoming; Billings and Carroll 2012), a negative relationship (Foster 1997), or a contingent relationship (Carr and Farmer 2011) between TELs and special districts. Nonetheless, there is a possibility that TELs are accounting for the relationship observed in table 2.

To test for this possibility, a dichotomous variable is introduced to the specifications in table 2 indicating if the state has a potentially binding tax and expenditure limitation on municipalities. Data for this is sourced from the now defunct Advisory Commission on Intergovernmental Relations (1995) and the work of Joyce and Mullins (1991), Mullins and Joyce (1996), and Mullins and Wallin (2004) forms the basis of the measurement of the presences and potential influence of TELs. First explained in Joyce and Mullins (1991) and expanded in Mullins and Wallin (2004), TELs come in seven varieties: overall property tax rate restrictions (applied to all governments), specific property tax rate restrictions (applied to specific types of local governments), property tax levy limits, general revenue increase limits, general expenditure increase limits, limits on assessment increases, and truth in taxation (full disclosure) requirements. The impact of each varies as to the extent that they bind the behavior of the target government. Joyce and Mullins (1991) adopt the language of non-binding and potentially binding to categorize individual TELs. Nonbinding TELs are easily circumvented by the target government. Potentially binding TELs are much more difficult to evade. These types of TELs are usually a collection of non-binding TELs, whose combined effect constrains behavior. The latter type is of interest to this analysis because we are interested in TELs that materially change the behavior of general purpose governments. A potentially binding TEL is indicated if the state imposes any of the following TELs: an overall or 
specific rate limit coupled with an assessment limit; a property tax levy limit; a general revenue or expenditure increase limit.

If TELs are the real source of the observed effect in table 2, the jurisdictional overlap variable should become insignificant when TEL dummy and interaction are introduced. As can be seen in table 3, model 2, jurisdictional overlap remains positive and statistically significant. Potentially binding TELs and the interaction of TELs and jurisdictional overlap are not statistically significant suggesting TELs have no independent or contingent influence on per capita public employment. This result suggests the positive relationship between jurisdictional overlap and per capita employment is not attributable to TELs.

\section{Conclusions \& Policy Implications}

The results of this analysis demonstrate that increased vertical layering of special districts is associated with more public employment per capita than would exist under the provision of similar services by a single general purpose local government. The difference in the size of the public workforce under vertical layering versus a general purpose local government is quantitatively small; nowhere near the effect size found by Berry (2008) of nearly 10 percent of local revenues. There is little indication that this finding is due to TEL-induced special district formation. However, there is evidence this increased level of public employment associated with jurisdictional overlap is partially attributable to an increase in the number of functions provided in a local area. Some possibilities for the discrepancy between the findings here and that of Berry (2008) special districts are ultimately acting as pass through entities for municipal debt with few actual employees. Additionally, special districts could be acting as outsourcing agents; collecting revenues and paying other organizations (special districts, cities, counties, or non- or for-profits) to deliver services. The latter possibility would fit with the perception of special districts as more businesslike entities (Berman and West 2011). More research is necessary to empirically explore these possibilities.

A necessary comparison of these results is to previous findings on the relationship between local government arrangement and public employment. A key contribution of this analysis is the exploration of the local vertical arrangement; however, much prior research focuses on the horizontal aspect. Schneider (1989a) suggests that non-overlapping, horizontal competition between municipalities is a means to limit the size of the local public workforce. The results presented here focusing on vertical competition between overlapping special districts suggests a countervailing force increasing the size of the local public workforce. As much of the growth in local government in the last half century has been in the vertically overlapping form, these findings would allude to the domination of municipal competition by the "overlap effect."

In general, the extant literature is hesitant to endorse the expanded usage of vertically arranged local governments for two primary reasons. First, a common refrain in support of increased special district usage is to expand or increase the quality of local public services. Indeed, the results from table 3, panel A partially supports this proposition. However, there is no systematic evidence that general purpose local governments are under-providing local public services and, where local public services are under-provided, it is unclear that the additional cost associated with special districts improves service delivery Berry 2008; Foster 1997. Second, while it is clear that increased usage of special districts increases specialization, it is unclear that the benefits of specialization (expertise) result in any identifiable increase in the quality of public services (Foster 1997). Indeed, 
as Foster (1997) finds, the mix of public services provided under a specialized regime tends to differ from a generalized regime. To the extent that specialization changes to mix of public services provided to ones that are not necessarily demanded by the decisive citizen-voter, public service provision by special district can be welfare diminishing. Pertinent to this analysis, it is unclear if additional local public sector employees as the result of jurisdictional overlap improves the quality public service provision.

Regardless of the potential improvements in service provision from special districts, a necessary comment is whether that improvement is worth the cost to the democratic process. As mentioned previously, special district elections are exempt from the one person/one vote requirement (Briffault 1993; Burns 1994). As a result, voting rights can be apportioned on the basis of any number of bases with owning property within the district being particularly popular. In 1987, approximately 14 percent of all special districts elected at least one representative through property ownership (Bauroth 2007). If this percentage still holds today, this would constitute more than 5,000 districts; not an insignificant number of governments. Burns (1994) argues that special districts appear to go out of their way to limit political participation. As a result, participation in special district elections is low. Bauroth (2007) notes that these limitations in voting rights have real impacts on the fiscal policies of special districts, favoring property owners' interests over the interest of the average or median resident. Even if the quality of public service provisions was elevated by specialized service delivery, the costs to local democracy may be too high to further endorse this institutional arrangement outside of a few, limited use cases.

\section{Notes}

${ }^{1}$ As opposed to a 2.1 percent increase in general purpose local governments over the same time period. The annualized growth rate for general purpose local governments is 0.03 percent per year, on average.

${ }^{2}$ Counties composed 3.4 percent, cities composed 21.7 percent, towns composed 18.2 percent, and independent school districts composed 14.4 percent of all local governments.

${ }^{3}$ An exception to this lack of support was for metropolitan wide special districts. Though these types of governments were seen as a poor substitute for a single, metropolitan government.

${ }^{4}$ The U.S. Census Bureau (2013) notes that the administrative independence dimension is often violated, even when the special purpose entity has significant fiscal independence.

${ }^{5}$ One of the primary issues for the reform movement in public administration in regards to local government fragmentation was the ability of one, metro-wide government to internalize the costs of public service provision.

${ }^{6}$ See Bauroth (2005) for a further discussion of the uniqueness of special district elections.

${ }^{7}$ Ultimately, the flexibility and responsiveness of special districts to special interests may pose a significant accountability problem (Foster 1997). It is likely the lack of accountability is one sources of the commons problem outlined.

${ }^{8}$ The town or township form of government presents a potential issue in this formulation. Towns are only allowed in 20 states and in 11 of those states, towns have characteristics more similar to special purpose governments than municipalities. Specifically in Connecticut, Illinois, Indiana, Kansas, Michigan, Minnesota, Missouri, Nebraska, New York, Ohio, and Vermont, towns may overlap municipalities in a similar manner to special purpose governments. In Maine, Massachusetts, New Hampshire, New Jersey, North Dakota, Pennsylvania, Rhode Island, South Dakota, and Wisconsin, towns have no overlap with municipalities. Following Berry $(2008,2009)$, towns in the 11 states that allow overlap are classified as special purpose local governments and in the 9 states that allow no overlap classify towns as municipalities.

${ }^{9}$ The two independent cities were chosen because it simplifies the example. Both are county-equivalents and are free of other municipalities as well a county government.

${ }^{10}$ There are county areas where the jurisdictional overlap ratio is zero. Rather than drop these cases (the logarithm of zero is undefined), one is added to jurisdictional overlap before transforming the variable. In many cases, these are independent cities Virginia and are dropped from the analysis. Similar to Berry (2008), the results are not appreciably different if these observations are excluded.

${ }^{11} \mathrm{~A}$ list of the eliminated county areas or independent cities is available upon request. 


\footnotetext{
${ }^{12} \mathrm{~A}$ requirement of this type of estimation is that while the error term may exhibit first-order serial correlation, second-order serial correlation must be absent. Testing for this phenomenon on a base model without jurisdictional overlap using the Arellano and Bond (1991) AR[1] and AR[2] tests demonstrates an AR[1] process but not an AR[2].

${ }^{13}$ This percent change in calculated as $\left(e^{0.012 * \ln (2.3)}-1\right) * 100$.

${ }^{14} \mathrm{~A} 10$ percent change in the primary result is calculated as $\left(e^{0.013 * \ln (1.1)}-1\right) * 100$.

${ }^{15}$ TELs are often imposed on independent school districts. See Mullins and Wallin (2004) for a complete enumeration of such limits.
}

\section{References}

Advisory Commission on Intergovernmental Relations. 1995. Tax and Expenditure Limitations on Local Governments. Bloomington, IN: Center for Urban Policy / the Environment, Indiana University.

— . 1987. The Organization of Local Public Economies. Washington, D.C.: Government Printing Office.

- .1964. The Problem of Special Districts in American Government: A Commission Report. Washington, D.C.: Government Printing Office.

Arellano, Manuel, and Stephen Bond. 1991. "Some Tests of Specification for Panel Data: Monte Carlo Evidence and an Application to Employment Equations." The Review of Economic Studies 58 (2): 277-297.

Arellano, Manuel, and Olympia Bover. 1995. "Another Look at the Instrumental Variable Estimation of Error-Components Models." Journal of Econometrics 68 (1): 29-51.

Bahl, Roy W., Richard D. Gustely, and Michael J. Wasylenko. 1978. "The Determinants of Local Government Police Expenditures: A Public Employment Approach." National Tax Journal 31 (1): 67-79.

Bauroth, Nicholas. 2007. "The Effect of Limiting Participation in Special District Elections of Property Owners: A Research Note." Public Budgeting \& Finance 27 (3): 71-89.

— .2005. "The Influence of Elections on Special District Revenue Policies: Special Democracies or Automatons of the State." State \& Local Government Review 37 (3): 193-205.

Berman, Evan M., and Jonathan P. West. 2011. "Public Values in Special Districts: A Survey of Managerial Commitment." Public Administration Review 72 (1): 43-54.

Berry, Christopher R. 2009. Imperfect Union: Representation and Taxation in Multilevel Governments. Cambridge: Cambridge University Press.

— . 2008. "Piling On: Multilevel Government and the Fiscal Common-Pool." American Journal of Political Science 52 (4): 802-820.

Billings, Stephen B., and Deborah A. Carroll. 2012. "Debrucing the Link Between Tax and Expenditure Limits and Special District Governments." Growth and Change 43 (2): 273-303.

Blundell, Richard, and Stephen Bond. 1998. "Initial conditions and moment restrictions in dynamic panel data models." Journal of Econometrics 87 (1): 115-143.

Bollens, John C. 1957. Special District Governments in the United States. Berkeley and Los Angeles: University of California Press.

Briffault, Richard. 1993. "Who Rules at Home? One Person/One Vote and Local Governments." University of Chicago Law Review 60 (2): 339-424. 
Burns, Nancy. 1994. The Formation of American Local Governments: Private Values in Public Institutions. New York, NY: Oxford University Press.

Carr, Jered B., and Jayce Farmer. 2011. "Contingent Effects of Municipal and County TELs on Special District Usage in the United States." Publius: The Journal of Federalism 41 (4): 709-733.

Ehrenberg, Ronald G. 1973. "The Demand for State and Local Government Employees." American Economic Review 63 (3): 366-379.

- . 1972. The Demand for State and Local Government Employees: An Economic Analysis. Lexington, MA: Lexington Books.

Ferris, James M., and Elizabeth Graddy. 1991. "Production Costs, Transactions Costs and Local Government Contractor Choice." Economic Inquiry 29 (3): 541-554.

Foster, Kathryn A. 1997. The Political Economy of Special-Purpose Government. Washington D.C.: Georgetown University Press.

Goodman, Christopher B. Forthcoming. "Usage of Specialized Service Delivery: Evidence from Contiguous Counties." Publius: The Journal of Federalism.

Goodman, Christopher B., and Suzanne M. Leland. 2012. "Cost shocks and their relationship to the creation, consolidation and dissolution of US local governments." Public Finance E Management 13 (2): 58-79.

Hudson, Kari. 1996. "Special District Governments: Examining the Questions of Control." American City $\mathcal{E}$ County ().

Joyce, Phillip G., and Daniel R. Mullins. 1991. "The Changing Fiscal Structure of State and Local Public Sector: The Impact of Tax and Expenditure Limitations." Public Administration Review 51 (3): 240-253.

Leigland, James. 1990. “The Census Bureau's Role in Research on Special Districts: A Critique." Western Political Quarterly 43 (2): 367-380.

Little Hoover Commission. 2000. Special Districts: Relics of the Past or Resources for the Future. Sacramento: Little Hoover Commission.

Mullin, Megan. 2008. "The Conditional Effect of Specialized Governance on Public Policy." American Journal of Political Science 52 (1): 125-141.

Mullins, Daniel R., and Phillip G. Joyce. 1996. "Tax and Expenditure Limitations and State and Local Fiscal Structure: An Empirical Assessment." Public Budgeting E Finance 16 (1): 75-101.

Mullins, Daniel R., and Bruce A. Wallin. 2004. “Tax and Expenditure Limitations: Introduction and Overview." Public Budgeting and Finance 24 (4): 2-15. ISSN: 02751100.

Nelson, Michael A. 1990. "Decentralization of the Subnational Public Sector: An Empirical Analysis of the Determinants of Local Government Structure in Metropolitan Areas in the US." Southern Economic Journal 57 (2): 443-457.

Olson, Mancur. 1965. The Logic of Collective Action: Public Goods and the Theory of Groups. Cambridge: Harvard University Press.

Ostrom, Vincent, Charles M. Tiebout, and Robert Warren. 1961. "The Organization of Government in Metropolitan Areas: A Theoretical Inquiry." American Political Science Review 55 (4): 831-842. 
Schneider, Mark. 1989a. "Intercity competition and the size of the local public work force." Public Choice 63 (3): 253-265.

— . 1989b. The Competitive City: The Political Economy of Suburbia. Pittsburgh: University of Pittsburgh Press.

— . 1988. "The Demand for the Suburban Public Work Force: Residents, Workers, and Politicians." The Journal of Politics 50 (1): 89-107.

Stein, Robert M. 1989. "Market Maximization of Individual Preferences and Metropolitan Service Responsibility." Urban Affairs Review 25 (1): 86-116.

— . 1984. "Municipal Public Employment: An Examination of Intergovernmetnal Influences." American Journal of Political Science 28 (4): 636-653.

Stephens, G. Ross, and Nelson Wikstrom. 1998. "Trends in special districts." State and Local Government Review 30 (2): 129-138.

Stigler, George J. 1971. "The Theory of Economic Regulation." The Bell Journal of Economics and Management 2:3-21.

Tiebout, Charles M. 1956. "A Pure Theory of Local Expenditures." Journal of Political Economy 64 (5): 416-424.

U.S. Census Bureau. 2013. 2012 Census of Governments, Individual State Descriptions. Washington, D.C.: Government Printing Office. 